Q

The article is still iress:

Neurosci Biobehav Rev. 2017 May 18. pii: S0149-7634(16)30726-6. doi: 10.1016/j.neubiorev.2017.05.016. [Epub ahead of print]

\title{
Systematic review and meta-analysis on the relationship between prenatal stress and metabolic syndrome intermediate phenotypes
}


Adriana L. Burgueño, 1

Yamila R. Juarez, 1

Ana M. Genaro, 1

Mariana L. Tellechea, $2 \square$

Emailmtellechea@cedie.org.ar

1 Instituto de Investigaciones Biomédicas, Consejo Nacional de Investigaciones Científicas y Técnicas (CONICET) - Pontificia Universidad Católica Argentina, Alicia Moreau de Justo 1600, C1107AFF Buenos Aires, Argentina

2 Centro de Investigaciones Endocrinológicas "Dr. César Bergadá", Consejo Nacional de Investigaciones Científicas y Técnicas-Fundación de Endocrinología Infantil—División de Endocrinología-Hospital de Niños Ricardo Gutiérrez, Gallo 1330, C1425EFD Buenos Aires, Argentina

Received: 26 February 2019 / Accepted: 2 June 2019

\section{Abstract}

\section{Background}

Metabolic Syndrome (MetS) can be considered as a consequence of a complex interplay between genetic and environmental factors and can be influenced by changes in the environment early in life. Prenatal stress (PS) exposure likely represents an important adverse intrauterine environment that may impact the biology of the developing organism. The aim of this study was to quantitatively synthesize the available data on the effects of PS on offspring's obesity, estimated indirectly by body mass index (BMI) and body fat; blood pressure, plasma glucose and blood lipid concentrations (triglycerides and high-density lipoprotein cholesterol). 


\section{Methods}

Literature searches for eligible studies on PubMed were conducted until October 8, 2018. Full text review yielded 24 publications for inclusion into the systematic review. Meta-analyses were performed for the outcomes BMI and body fat. 62 effect sizes from 19 studies together with relevant moderators were collected. Summary estimates were calculated by using random-effects model.

\section{Results}

The combined standardized mean difference $(d)$ for the relation between BMI and PS indicated that despite significant heterogeneity, stress exposure of expectant mothers was associated with increased BMI of their offspring $[d$ $(95 \%$ CI $)=0.268(0.191 ; 0.345)]$. Both objective and subjective stress have been linked to increased overweight. Preliminary results of the relationship between PS and body fat suggested that the contribution of PS to body fat should be at least further considered $[d(95 \% \mathrm{CI})=0.167(0.016 ; 0.317)]$. Evidence from a limited number of published studies do not sustains an effect on blood pressure, glucose metabolism or circulating lipids, however these outcomes have only been scarcely investigated.

\section{Conclusions}

A direct association between PS and BMI was found and further studies are needed to confirm the relationship between maternal stress during gestation and body fat. Overall, findings suggest that PS could contribute to alterations to the post-natal offspring phenotype.

These authors contributed equally: Adriana L. Burgueño, Mariana L. Tellechea

\section{Introduction}

Stress appears to be an emerging risk and prognostic factor for earlier onset of complex, common age-related diseases [1]. It is well recognized that in modern society the adverse effects of stress on health have been increasing [2]. There are several, competing uses of the term stress but is often defined as a threat to physiological and/or psychological homeostasis. Accordingly, stressors are 
stimuli that can trigger physiological, emotional, and/or behavioral reactions of distress when perceived as exceeding available resources [2].

The Developmental Origins of Health and Disease (DOHaD) theory, also called fetal programming hypothesis, states that perturbations in early life could program metabolic functions and lead to adverse cardio-metabolic outcomes later in life, such as obesity, Metabolic Syndrome (MetS) and Cardiovascular Disease [3]. Both genetic and environmental factors, including the in utero environment, play important roles in the development of complex common multifactorial disorders. The fetal programming concept has been nowadays widely incorporated highlighting the importance of the non-genetic susceptibility for metabolic disease. Studies concerning the effects of stressors on pregnant women have taken a special position in stress research. Prenatal stress (PS) exposure likely represents yet another important adverse intrauterine environment that may impact the biology of the developing organism [4]. As the global burden of metabolic disorders is escalating, the contribution of PS to metabolic health represents an important area of research [4]. Nutritional and non-nutritional stresses during pregnancy due to factors such as infection or maternal physical or psychological trauma can lead to consequences for the fetus that are detrimental to health [5]. Studies on maternal starvation from preconception to early infancy, as in the Dutch famine in the World War II, or exposure to stressful events in the Holocaust have shown associations between early stress and ulterior obesity and associated metabolic disorders $[6,7,8,9$, $10]$.

The effects of PS are thought to operate mainly through glucocorticoids (cortisol in humans and other mammals, corticosterone in rodents), catecholamines (adrenaline and noradrenaline), and neuropeptides such as corticotrophinreleasing hormone [9]. Additionally, studies have reported that elevated stress in pregnant women is associated with elevated serum pro-inflammatory cytokines [11]. Besides endocrine and immune processes, in-utero exposure to PS would be associated with potential maternal nutritional and life style changes affecting the fetus.

The involvement of the hypothalamic pituitary adrenal (HPA) axis in PS has received extensive consideration. Glucocorticoids may be passed on from the mother to the fetus through the placenta [12], however, the placental enzyme $11 \beta$-hydroxysteroid dehydrogenase type 2 (11ß-HSD2) catalyzes the rapid inactivation of glucocorticoids (cortisol and corticosterone) to physiologically inert forms, providing a protective barrier between the fetus and mother [13, 14]. It has been hypothesized that reduced placental 11 $\beta$-HSD2 activity results in high levels of glucocorticoids reaching the fetus, which retard growth and 
program susceptibility to disease $[15,16,17]$. Maternal physiological stress increases the levels of maternal glucocorticoids to levels that may overcome the placental $11 \beta$-HSD2 barrier and additionally reduce placental $11 \beta$-HSD2 levels/activity $[18,19]$.

It is plausible that programmed changes in the HPA axis activity contribute to the risk of MetS. Littleton et al. [20] have conducted a meta-analysis to evaluate the relationship between psychosocial stress in pregnancy and negative perinatal outcomes. PS has been shown to affect both neonatal weight and risk for low birth weight. Owing to the inverse correlations that have been reported between size at birth and MetS in adult life [21,22], this finding supports the hypothesis of association between PS and MetS. Edwards et al. [13] have suggested that the association between low birth weight and the subsequent development of common disorders of adult life, especially hypertension, are related to increased fetal exposure to maternal glucocorticoids. Furthermore, a meta-analysis has found an inverse association between birth weight and circulating cortisol levels also suggesting a possible role of the HPA axis in the epidemiological association between birth weight and cardiovascular disease [23]. The potential role of glucocorticoids underlying the link between low birth weight and the later development of obesity and diabetes is reviewed elsewhere [24].

The experience of PS has also been shown to affect a range of long-term outcomes. Growing evidence from animal and human studies suggests that inutero exposure to PS may impact the developing fetus to produce increased susceptibility for offspring MetS intermediate phenotypes, obesity, dysregulated glycaemic control, hypertension and dyslipidaemia [25]. A study has found evidence to suggest that exposure to stressful conditions during preconception and the prenatal period may increase the risk for developing Type 2 Diabetes Mellitus in childhood and young adulthood [26]. In this context we designed a systematic review to summarize and quantify through meta-analyses, the longterm metabolic effects of the exposure to PS. We collected and analyzed the available data from the literature on humans regarding the short and long-term influence of PS on intermediate phenotypes of the MetS such as body mass index (BMI), including body fat and leptin levels; blood pressure; blood glucose including insulin concentration; triglycerides and high-density lipoprotein cholesterol (HDL-C) levels. The influence of biological and experimental moderators was evaluated by using subgroup analysis and meta-regression.

\section{Materials and methods}

\section{Search strategy}


Literature searches were done on studies up to October 8, 2018 on PubMed. We followed the appropriate methods for conducting a meta-analysis as reported in the Guidelines for Meta-Analyses of Observational Studies in Epidemiology group and PRISMA (Preferred Reporting Items for Systematic Reviews and Meta-Analyses) statement [27, 28]. A review protocol was strictly followed (available under request) and a PRISMA checklist is included in Supplementary Information (SI) 1. The search strategy combines terms related to the exposure and outcomes of interest (SI 2). Specifically, selected outcomes were BMI or waist circumference if available, body fat or leptin levels, blood pressure, glucose, insulin, triglycerides, and HDL-C.

\section{Inclusion and exclusion criteria}

Studies were included in the meta-analyses if they assessed any measure of stress that mothers have experienced before offspring's birth and include outcomes in the postnatal period. Searches were restricted to studies on humans that were published in English and no offspring age limits were used. There were no country restrictions and eligible studies had no minimum number of participants. Studies were excluded if they assessed nutritional stress, stressrelated behaviors in pregnancy (e.g., smoking) or glucocorticoid exposure during prenatal life. Finally, studies that evaluated a related but distinct construct (e.g., cognitive appraisal) were excluded. Prenatal psychopathologic traits, anxiety (or pregnancy related anxiety) and depression were also excluded as prior recent reviews had assessed the association between these constructs and perinatal outcomes $[29,30]$. Exceptions were studies were anxiety and/or depression were included in a composite stress index.

Studies were excluded from meta-analyses and included in systematic review if data necessary to calculate an effect size could not be obtained from the study but any statistic was reported.

\section{Data collection and data analysis}

Data collection is described in SI 3 and the quality of individual studies was assessed at the outcome level using an adapted version of the Newcastle-Ottawa Scale [31] (NOS, SI 4).

All calculations were performed using the Comprehensive Meta-Analysis (CMA) computer program (Biostat, Englewood, NJ, USA) as previously described [32]. Effect sizes (standardized mean difference, d) with confidence intervals were calculated and summary estimates were calculated using random effects models. Forest plots were generated to illustrate the study-specific effect sizes along with $95 \%$ CI. Sensitivity analysis removing one study at a time was 
performed to investigate the influence of each study on the overall result [33]. Heterogeneity was evaluated with the Q statistic and I-squared statistic. Measures of heterogeneity of $25 \%, 50 \%$, and $75 \%$ were considered low, moderate, and high, respectively [34]. A priori subgroup analyses based on type of stress (objective vs. subjective), study design, source of dataset, intervention span and age stage were conducted to examine possible sources of heterogeneity. In mixed effects analysis a random effects model was used to combine studies within each subgroup. For mixed effects analysis a $p$-value of less than 0.1 indicates a statistically significant subgroup effect. Meta-regression analysis was also performed to assess the influence of age, proportion of male participants, quality score, sample size and year of publication. Further sensitivity analyses, also specified a priori, were conducted to observe the impact of removing studies at risk of bias: (1) studies where ascertainment of exposure was not assessed by structured interview or questionnaire, (2) studies scoring three or less in quality level, and finally (3) studies reporting standardized regression coefficients, instead of correlation $r$ to verify the possible influence of those studies on estimates. To check for publication bias we used the Egger's test and visual inspection of funnel plots. A $p$-value $<0.05$ was considered to be statistically significant unless otherwise stated.

\section{Results}

\section{Eligible studies and characteristics}

A flow diagram schematizing the process of article exclusion is summarized in Fig. 1. Full text review yielded 24 publications for inclusion into the systematic review and meta-analyses $[35,36,37,38,39,40,41,42,43,44,45,46,47,48$, $49,50,51,52,53,54,55,56,57,58]$. The list of excluded studies with reasons for exclusion is available in SI 5.

\section{Fig. 1}

PRISMA flow chart summarizing study selection processes for systematic review and meta-analysis in humans 


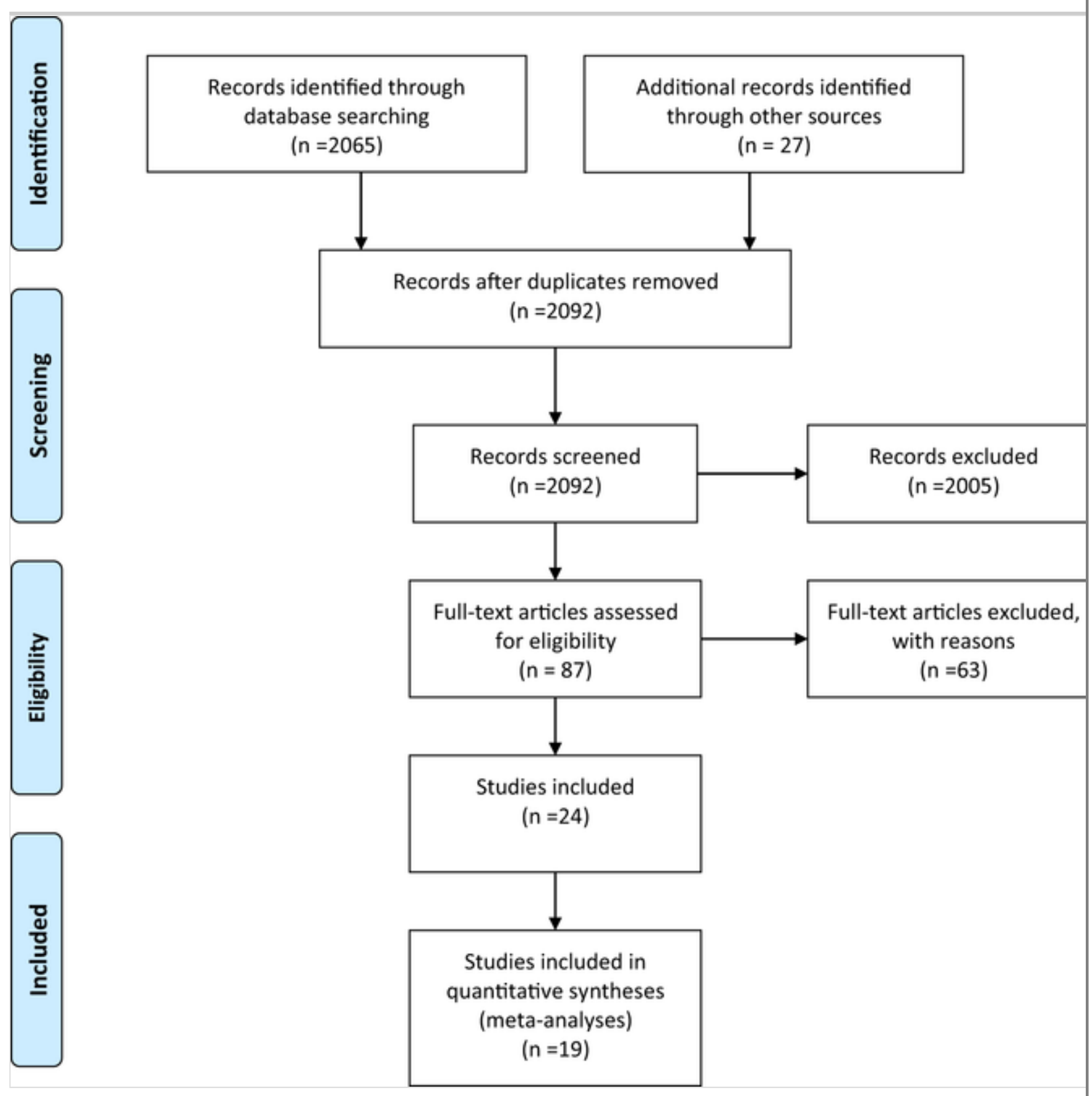

We performed two separate meta-analyses for BMI and body fat datasets.

Table 1 altogether with SI 6 illustrate the characteristics of the 19 included studies [35, 36, 37, 38, 39, 40, 41, 42, 43, 44, 45, 46, 47, 48, 49, 53, 55, 56, 58]. Thirteen studies included a relatively similar amount of males and females. The range age of participants was $0.25-38.9$ years. Studies were conducted in both developed and developing countries, and some studies were conducted in specific ethnic groups (e.g., Mexican, Chinese and US racial/ethnic minorities). In general, studies have included both primigravida and multigravida women.

\section{Table 1}

Characteristics of included studies 


\begin{tabular}{|c|c|c|c|c|c|c|}
\hline Study & Dataset & Design & Country & $\begin{array}{c}\% \\
\text { Ethnicity }\end{array}$ & $\begin{array}{c}\% \\
\text { Male }\end{array}$ & Exposure \\
\hline Bhat [35] & $\begin{array}{l}\text { Hospital } \\
\text { level }\end{array}$ & Current & Australia & $\sim 0$ & 47.7 & $\begin{array}{l}\text { Life stress } \\
\text { events }\end{array}$ \\
\hline $\begin{array}{l}\text { Chatterjee } \\
{[36]}\end{array}$ & $\begin{array}{l}\text { Town } \\
\text { level }\end{array}$ & Current & Mexico & $\sim 100$ & 51 & $\begin{array}{l}\text { Perceived } \\
\text { stress }\end{array}$ \\
\hline $\begin{array}{l}\text { Christensen } \\
{[37]}\end{array}$ & $\begin{array}{l}\text { Country } \\
\text { level }\end{array}$ & Historical & Denmark & $\sim 0$ & 51.3 & $\begin{array}{l}\text { Road traffic } \\
\text { noise }(<55 \\
\text { dB vs. } \geq 55 \\
\text { dB })\end{array}$ \\
\hline $\begin{array}{l}\text { Dancause } \\
{[38]^{\mathrm{a}}}\end{array}$ & \multirow{2}{*}{$\begin{array}{l}\text { Regional } \\
\text { level }\end{array}$} & \multirow{2}{*}{ Current } & \multirow{2}{*}{ Canada } & \multirow{2}{*}{$\sim 0$} & \multirow{2}{*}{56,2} & $\begin{array}{l}\text { Ice storm- } \\
\text { related } \\
\text { objective } \\
\text { hardship }\end{array}$ \\
\hline $\begin{array}{l}\text { Dancause } \\
{[38]^{\mathrm{b}}}\end{array}$ & & & & & & $\begin{array}{l}\text { Ice storm- } \\
\text { related } \\
\text { subjective } \\
\text { distress }\end{array}$ \\
\hline $\begin{array}{l}\text { Dancause } \\
{[39]^{a, b}}\end{array}$ & \multirow{2}{*}{$\begin{array}{l}\text { Regional } \\
\text { level }\end{array}$} & \multirow{2}{*}{ Current } & \multirow{2}{*}{ USA } & \multirow{2}{*}{$\sim 0$} & \multirow{2}{*}{54.7} & $\begin{array}{l}\text { Flood- } \\
\text { related } \\
\text { objective } \\
\text { hardship }\end{array}$ \\
\hline $\begin{array}{l}\text { Dancause } \\
{[39]^{\mathrm{c}, \mathrm{d}}}\end{array}$ & & & & & & $\begin{array}{l}\text { Flood- } \\
\text { related } \\
\text { subjective } \\
\text { distress }\end{array}$ \\
\hline Dixon [40] & $\begin{array}{l}\text { Regional } \\
\text { level }\end{array}$ & Current & USA & $\sim 100$ & 50.7 & $\begin{array}{l}\text { Experiences } \\
\text { of racism (0 } \\
\text { vs. } 3+)\end{array}$ \\
\hline $\begin{array}{l}\text { Entriger } \\
{[41]}\end{array}$ & $\begin{array}{l}\text { Regional } \\
\text { level }\end{array}$ & Historical & Germany & $\sim 0$ & 17.2 & $\begin{array}{l}\text { Negative life } \\
\text { events }\end{array}$ \\
\hline $\begin{array}{l}\text { Farewell } \\
{[42]^{\mathrm{a}, \mathrm{b}}}\end{array}$ & \multirow{2}{*}{$\begin{array}{l}\text { Regional } \\
\text { level }\end{array}$} & \multirow{2}{*}{ Current } & \multirow{2}{*}{$\begin{array}{l}\text { New } \\
\text { Zealand }\end{array}$} & \multirow{2}{*}{41.4} & \multirow{2}{*}{51.4} & $\begin{array}{l}\text { Objective } \\
\text { vulnerability }\end{array}$ \\
\hline $\begin{array}{l}\text { Farewell } \\
{[42]^{\mathrm{c}, \mathrm{d}}}\end{array}$ & & & & & & $\begin{array}{l}\text { Perceived } \\
\text { stress }\end{array}$ \\
\hline $\begin{array}{l}\text { Guxens } \\
{[43]^{\mathrm{a}-\mathrm{g}}}\end{array}$ & \multirow{2}{*}{$\begin{array}{l}\text { Regional } \\
\text { level }\end{array}$} & \multirow{2}{*}{ Current } & \multirow{2}{*}{$\begin{array}{l}\text { The } \\
\text { Netherlands }\end{array}$} & \multirow{2}{*}{$\sim 38.3$} & \multirow[t]{2}{*}{50.6} & $\begin{array}{l}\text { Distress } \\
\text { related to } \\
\text { hostility }\end{array}$ \\
\hline $\begin{array}{l}\text { Guxens } \\
{[43]^{\mathrm{h}-\mathrm{n}}}\end{array}$ & & & & & & Family stress \\
\hline $\begin{array}{l}\text { Hohwu } \\
{[44]}\end{array}$ & $\begin{array}{l}\text { Specific } \\
\text { sub- } \\
\text { group }\end{array}$ & Historical & Denmark & $\sim 0$ & 100 & $\begin{array}{l}\text { Bereavement } \\
\text { (exposed vs. } \\
\text { not) }\end{array}$ \\
\hline
\end{tabular}

Data on ethnicity and \% male are approximations taken from data on the original cohort which individuals were taken. Superscripts indicate different datasets. 


\begin{tabular}{|c|c|c|c|c|c|c|}
\hline Study & Dataset & Design & Country & $\begin{array}{c}\% \\
\text { Ethnicity }\end{array}$ & $\begin{array}{c}\% \\
\text { Male }\end{array}$ & Exposure \\
\hline $\begin{array}{l}\text { Hohwu } \\
{[45]}\end{array}$ & $\begin{array}{l}\text { Hospital } \\
\text { level }\end{array}$ & Current & Denmark & $\sim 0$ & 49.3 & $\begin{array}{l}\text { Separation } \\
\text { (vs. } \\
\text { cohabiting } \\
\text { parents) }\end{array}$ \\
\hline $\begin{array}{l}\text { Ingstrup } \\
{[46]}\end{array}$ & $\begin{array}{l}\text { Country } \\
\text { level }\end{array}$ & Historical & Denmark & $\sim 0$ & 51.2 & $\begin{array}{l}\text { Feeling } \\
\text { stressed (a } \\
\text { lot vs. a } \\
\text { little) }\end{array}$ \\
\hline Ji [47] & $\begin{array}{l}\text { Regional } \\
\text { level }\end{array}$ & Historical & China & $\sim 100$ & 75 & $\begin{array}{l}\text { Earthquake } \\
\text { (exposed vs. } \\
\text { not) }\end{array}$ \\
\hline $\operatorname{Li}[48]^{\mathrm{a}-\mathrm{g}}$ & $\begin{array}{l}\text { Town } \\
\text { level }\end{array}$ & Historical & Denmark & $\sim 0$ & 50.5 & $\begin{array}{l}\text { Bereavement } \\
\text { (exposed vs. } \\
\text { not) }\end{array}$ \\
\hline $\operatorname{Liu}[49]^{\mathrm{a}-\mathrm{e}}$ & \multirow{2}{*}{$\begin{array}{l}\text { Regional } \\
\text { level }\end{array}$} & \multirow{2}{*}{ Current } & \multirow{2}{*}{ Canada } & \multirow{2}{*}{$\sim 0$} & \multirow{2}{*}{$\begin{array}{l}50.5- \\
57.7\end{array}$} & $\begin{array}{l}\text { Ice storm- } \\
\text { related } \\
\text { objective } \\
\text { hardship }\end{array}$ \\
\hline Liu $[49]^{f-j}$ & & & & & & $\begin{array}{l}\text { Ice storm- } \\
\text { related } \\
\text { subjective } \\
\text { distress }\end{array}$ \\
\hline $\begin{array}{l}\text { Van Dijk } \\
{[53]}\end{array}$ & $\begin{array}{l}\text { Town } \\
\text { level }\end{array}$ & Current & $\begin{array}{l}\text { The } \\
\text { Netherlands }\end{array}$ & 10.5 & NA & $\begin{array}{l}\text { Job strain } \\
\text { (high vs. } \\
\text { low) }\end{array}$ \\
\hline Wang [55] & $\begin{array}{l}\text { Specific } \\
\text { sub- } \\
\text { groups }\end{array}$ & $\begin{array}{l}\text { Case- } \\
\text { control }\end{array}$ & China & $\sim 100$ & 74.4 & $\begin{array}{l}\text { Earthquake } \\
\text { (exposed vs. } \\
\text { not) }\end{array}$ \\
\hline Weyde [56] & $\begin{array}{l}\text { Town } \\
\text { level }\end{array}$ & Historical & Norway & $\sim 8.5$ & 51 & $\begin{array}{l}\text { Road traffic } \\
\text { noise }(<55 \\
\text { dB vs. } \geq 60 \\
d B)\end{array}$ \\
\hline $\begin{array}{l}\text { Zadzinska } \\
{[58]}\end{array}$ & $\begin{array}{l}\text { Town } \\
\text { level }\end{array}$ & Historical & Poland & $\sim 0$ & 48.1 & $\begin{array}{l}\text { Experience } \\
\text { of } \\
\text { stress/trauma }\end{array}$ \\
\hline
\end{tabular}

Data on ethnicity and \% male are approximations taken from data on the original cohort which individuals were taken. Superscripts indicate different datasets.

Data source varied between studies but most studies were population-based. Studies in general were carried out prospectively; however, different criteria were used for ascertainment of exposure. Exposure was registered during pregnancy in ten studies, besides in eight studies (historical cohorts) ascertainment of exposure was collected from existing records or health care 
registers, or assessed retrospectively through questionnaire/interview. For analytical purposes we classified PS type in objective and subjective and data on overall/composite stress were not collected except for one study not included in meta-analyses but included in systematic review [57].

The majority of studies included had a low risk of bias according to the modified NOS quality score, with only two studies scoring low quality score. Summary of data included in meta-analyses is available on SI 7. Sample size ranged from 28 to 111,651 participants.

Other outcomes of interest have scarcely been investigated and for this reason meta-analyses were not performed. Table SI 8 illustrates the characteristics of the studies excluded from meta-analyses but included in systematic review [50, $51,52,54,57]$.

\section{Systematic review and meta-analysis on the relationship between PS and BMI}

The search process resulted in 18 studies (53 data points) included in the metaanalysis. Included studies reported the relationship between PS and a measure of offspring's obesity: BMI $\left(\mathrm{kg} / \mathrm{m}^{2}\right)$, BMI $z$-score or overweight. Measures of overweight were based on BMI or BMI z-score.

The combined weighted effect size for the relation between BMI and PS indicated that BMI was higher in prenatally stressed subjects than in control subjects $[d(95 \% \mathrm{CI})=0.268(0.191 ; 0.345)$, Fig. 2]. Sensitivity analysis indicated that no single study changed the pooled estimate qualitatively which suggested that the results of the meta-analysis were stable and reliable ( $d$ varied between 0.241 and $0.278 ; p$-values $<0.001)$. There was evidence of high heterogeneity between studies $[I$-squared $=97, p$-value $(Q)<0.001]$ and then subgroup analyses were performed (Table 2). The tests for subgroup differences suggested that there were significant subgroup effects, meaning that those moderators modified the effect of PS on BMI, specifically, there was evidence that the association between BMI and PS varied by dataset, design and age stage. Subgroup analysis includes the possibility of testing the robustness of associations across subgroups and interestingly, we identified that the association between PS and BMI was not significant in historical cohorts. Of note, substantial amount of unexplained heterogeneity between the studies included in each individual subgroup was detected.

\section{Fig. 2}

Forest plot for the associations between prenatal stress and BMI 


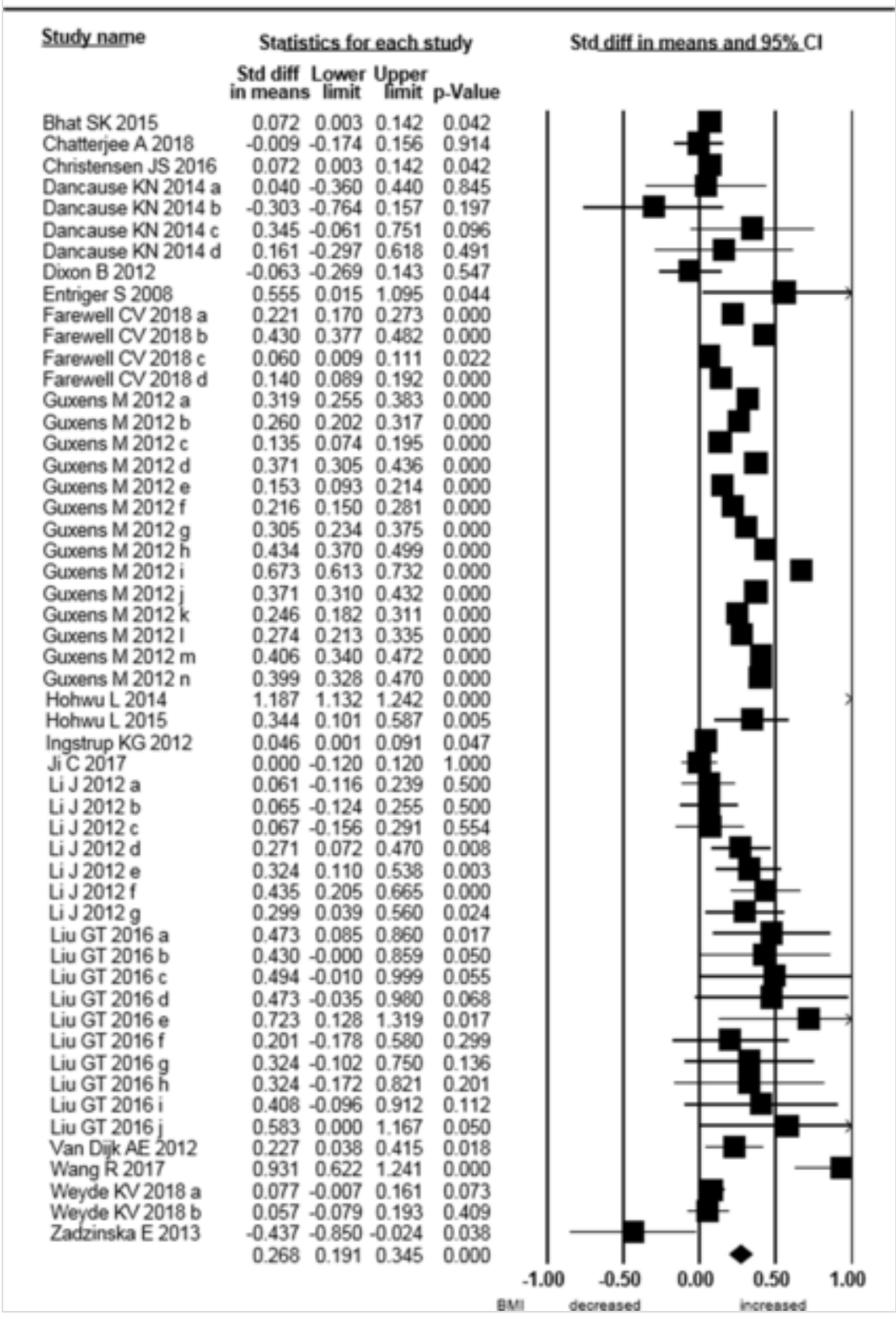

Table 2

Subgroup analysis

\begin{tabular}{|l|l|l|l|}
\hline \multirow{3}{*}{$N$} & \multicolumn{2}{|c|}{ Heterogeneity } & \multirow{2}{*}{} \\
\cline { 2 - 3 } & Q-value & $\begin{array}{c}\text { I- } \\
\text { squared }\end{array}$ & $\boldsymbol{d}(\mathbf{9 5} \% \mathrm{CI})$ \\
& &
\end{tabular}

Five moderators were analyzed. In mixed effects analysis a random effects model was used to combine studies within each subgroup. For this test a $p$-value of less than 0.1 indicates a statistically significant subgroup effect. Subgroups with less than five separate studies are not shown. $d=$ standardized mean difference. Column $N$ indicates number of subgroups (total between heterogeneity) or number of effect sizes ( $68^{\mathrm{with}}$

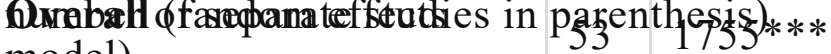 97 (0.191; ${ }^{*} p$-value $<0.05 ; * * p$-value $<0.01 ; * * * p$-value $<0.00001$ $0.345) * * *$ 


\begin{tabular}{|c|c|c|c|c|c|}
\hline \multirow[t]{2}{*}{ Dataset } & \multirow{2}{*}{ 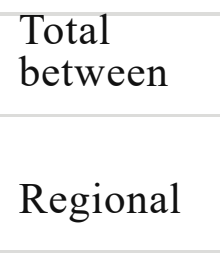 } & \multirow{2}{*}{$\begin{array}{l}5 \\
N \\
21\end{array}$} & \multicolumn{2}{|c|}{$\begin{array}{l}\mathbf{1 0 2}(\boldsymbol{p} \text {-value }< \\
\theta .00001)<\mathbf{0 . 0 0 0 0 1})^{\text {1eity }}\end{array}$} & \multirow[b]{2}{*}{$\begin{array}{l}\left.\boldsymbol{d}_{(\mathbf{9}} \mathbf{9 5} \% \mathrm{CI}\right) \\
(0.230 \\
0.323)^{* * *}\end{array}$} \\
\hline & & & $143^{* * *} Q$-value & $\begin{array}{c}I- \\
\text { squared }\end{array}$ & \\
\hline & Town & 26 & $341 * * *$ & 93 & $\begin{array}{l}0.253 \\
(0.190 \\
0.316)^{* * *}\end{array}$ \\
\hline \multirow[t]{3}{*}{ Design } & $\begin{array}{l}\text { Total } \\
\text { between }\end{array}$ & 3 & $\begin{array}{l}17(\boldsymbol{p} \text {-value }=0.0002) \\
=0.0002)\end{array}$ & & \\
\hline & Current & 37 & $481 * * *$ & 93 & $\begin{array}{l}0.273 \\
(0.214 ; \\
0.332)^{* * *}\end{array}$ \\
\hline & Historical & $\begin{array}{l}15 \\
(8)\end{array}$ & $1247 * * *$ & 99 & $\begin{array}{l}0206 \\
(-0.066 \\
0.478)\end{array}$ \\
\hline \multirow[t]{3}{*}{ Stress type } & $\begin{array}{l}\text { Total } \\
\text { between }\end{array}$ & 2 & $0(p$-value $=0.9)$ & & \\
\hline & Objective & 26 & $1196 * * *$ & 98 & $\begin{array}{l}0.278 \\
(0.106 ; \\
0.449)^{* *}\end{array}$ \\
\hline & Subjective & 27 & $490 * * *$ & 95 & $\begin{array}{l}0.261 \\
(0.192 \\
0.331)^{* * *}\end{array}$ \\
\hline \multirow[t]{3}{*}{$\begin{array}{l}\text { Intervention } \\
\text { span }\end{array}$} & $\begin{array}{l}\text { Total } \\
\text { between }\end{array}$ & 2 & $0(p$-value $=0.9)$ & & \\
\hline & Preges/ges & 18 & $29^{*}$ & 42 & $\begin{array}{l}0.252 \\
(0.158 \\
0.346)^{* * *}\end{array}$ \\
\hline & Ges & 35 & $1720 * * *$ & 98 & $\begin{array}{l}0.260 \\
(0.167 \\
0.352)^{* * *}\end{array}$ \\
\hline
\end{tabular}

Five moderators were analyzed. In mixed effects analysis a random effects model was used to combine studies within each subgroup. For this test a $p$-value of less than 0.1 indicates a statistically significant subgroup effect. Subgroups with less than five separate studies are not shown. $d=$ standardized mean difference. Column $N$ indicates number of subgroups (total between heterogeneity) or number of effect sizes (with Algelstage separate studies in parenthe.0.

$* p$-value $<0.05 ; * * p$-value $<0.01 ; * * * p$-value $<0.00001$ 


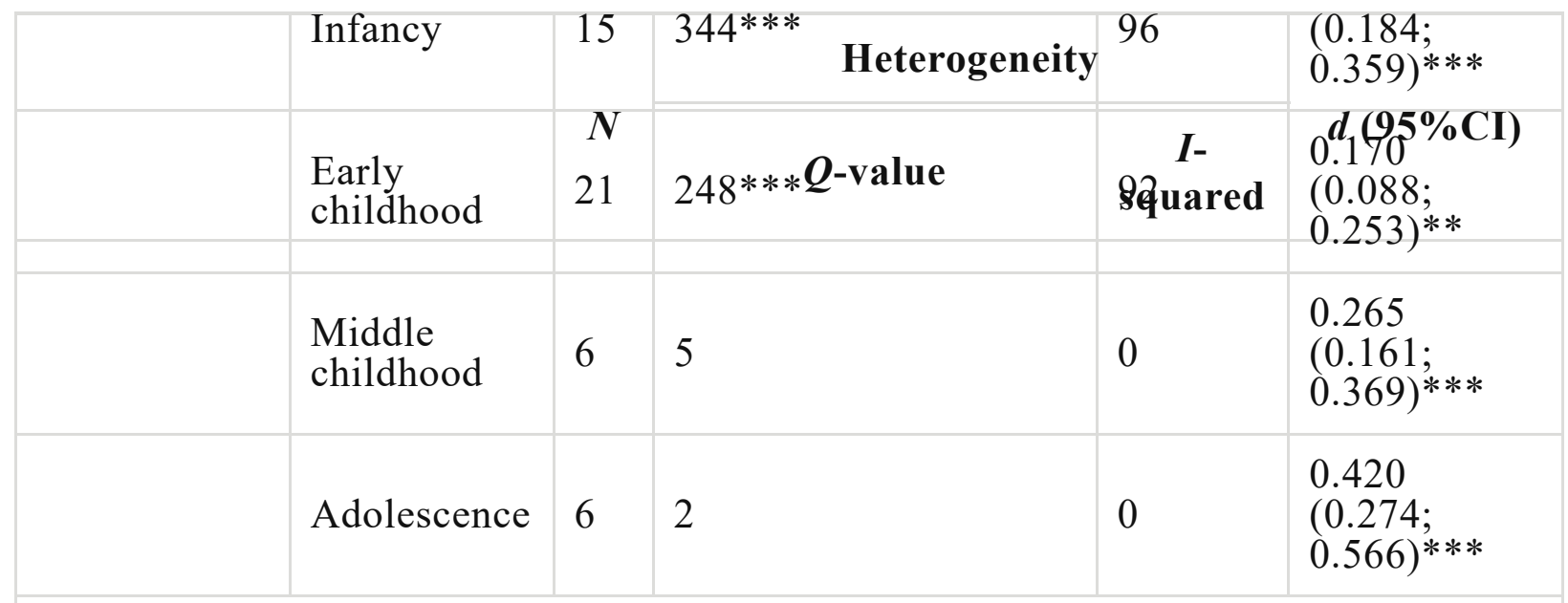

Five moderators were analyzed. In mixed effects analysis a random effects model was used to combine studies within each subgroup. For this test a $p$-value of less than 0.1 indicates a statistically significant subgroup effect. Subgroups with less than five separate studies are not shown. $d=$ standardized mean difference. Column $N$ indicates number of subgroups (total between heterogeneity) or number of effect sizes (with number of separate studies in parenthesis)

$* p$-value $<0.05 ; * * p$-value $<0.01 ; * * * p$-value $<0.00001$

By meta-regression analysis we further explored whether the effect size for the relation between PS and BMI was influenced by offspring's age, male ratio or ethnicity, and these analyses demonstrated that no moderator had a significant impact. Summaries of results from meta-regression are shown in SI 9. The male ratio in the sample seemed to have a positive effect on the relationship between PS and BMI $(Z>0)$; however, exclusion of one outlier study, conducted only in males (Hohwü 2014 [44]), resulted in loss of significance for this effect. Scatterplots are also available in SI 9.

Additionally, the effect of quality score, sample size and year of publication was explored by meta-regression but analysis demonstrated that these moderators had no significant impact. In addition, pre-specified sensitivity analyses were conducted to observe the impact of removing samples at risk of bias. High heterogeneity was still detected after exclusion of seven studies were ascertainment of exposure was not assessed by structured interview/questionnaire [I-squared $=93 \%, p$-value $(\mathrm{Q})<0.001, n=39]$. The random model pooled d was even significant $(d=0.256, p$-value $<0.001)$. In a different analysis we excluded two studies scoring three or less in quality level but heterogeneity was not resolved [I-squared $=97 \%, p$-value $(\mathrm{Q})<0.001, n=51]$ and the random model pooled estimate from the remaining studies was still significant $(d=0.253, p$-value $<0.001)$. Finally, when removing one study reporting standardized regression coefficients, both heterogeneity $[I$-squared $=$ $97 \%, p$-value $(\mathrm{Q})<0.001, n=39]$ and random model pooled estimate $(d=0.247$, $p$-value $<0.001)$ were still significant. 
At last, Egger's regression test was not significant (intercept $\pm \mathrm{ES}=-0.486 \pm$ 1.366) and the shape of the funnel plots seemed symmetrical, suggesting that publication bias might not have a significant influence on the result of this metaanalysis (SI 10).

One published research paper [50] meeting screening criteria was not included in meta-analysis because data necessary to calculate an effect size could not be obtained. This study reported no association between MS and BMI. More specifically, Sandel et al. [50] have studied the stress of homelessness during early development and found that prenatal homelessness was not associated with overweight in children $<4$ years old compared with children in the neverhomeless group. SI 11.1 show data extracted from the studies excluded from meta-analyses but included in systematic review.

\section{Systematic review and meta-analysis on the relationship between PS and adiposity}

Meta-analysis regarding body fat was just explorative because data on adiposity was extracted only from six studies, of which five ( 9 data points) were included in meta-analysis. One published research paper (Wu S [57]) was excluded from meta-analysis but included in systematic review. Different methods were used to estimate body fat: air-displacement plethysmography, bioelectrical impedance analysis and skinfold (SI 7).

The combined weighted effect size for the relation between body fat and PS indicated a significant positive relationship $[d(95 \% \mathrm{CI})=0.167(0.016 ; 0.317)$, Fig. 3], indicating that body fat was higher in prenatally stressed subjects than in controls. The leave-one-out sensitivity analysis indicated that excluding one study at a time changed the random model pooled estimates qualitatively (SI 12). The pooled estimates were marginally significant with $p$-values varying between 0.044 and 0.059 , except for exclusion of one specific dataset (Dixon B [40]) which turned pooled estimate significant $(p$-value $=0.001)$. Heterogeneity was not detected among studies [I-squared $=29 \%, p$-value $(Q)=0.2]$. Pre-specified sensitivity analyses was performed and excluding one study scoring three in quality level the random model pooled estimate was marginally significant $[d$ $(95 \% \mathrm{CI})=0.162(-0.001 ; 0.324), p=0.05, n=8]$. Egger's test for asymmetry of effect sizes (intercept $\pm \mathrm{ES}=1.751 \pm 0.629, p$-value $=0.03$ ) and the funnel plot did show some evidence for study bias (SI 10).

\section{Fig. 3}

Forest plot for the associations between prenatal stress and body fat. Estimates for standardized difference in means $(d$, effect); the corresponding 95\% CI (lower and 
upper) and significance ( $p$-value) were estimated by random effects analysis. The first author of the study and the year of publication are shown after study name. In the graph, numbers indicate $d$ values, filled squares stand for the effect of individual studies, and filled diamonds express combined fixed and random effects

\section{Meta Analysis}

Outcome: Body Fat

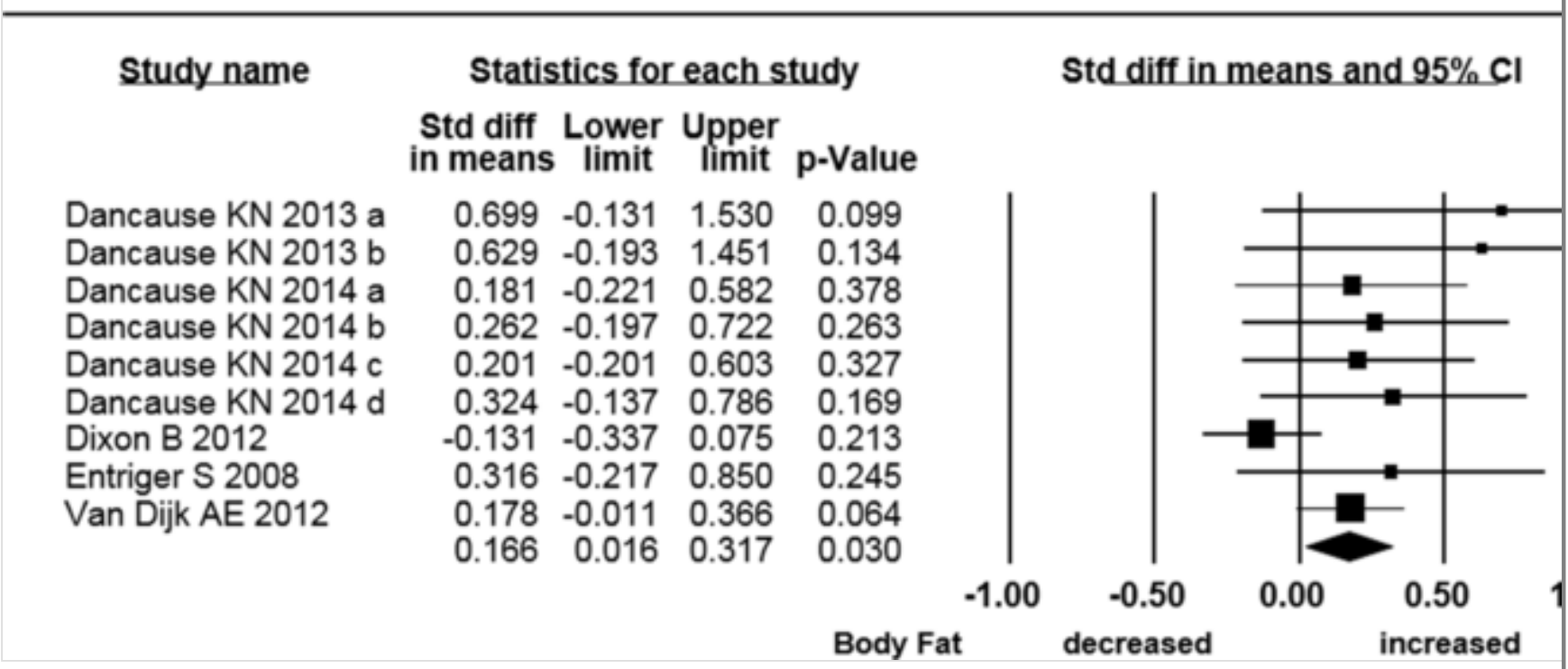

A negative association was reported in the one manuscript excluded from metaanalysis (Wu S [57]). In a cohort of mother-child pairs in Mexico City, an increase in a stress composite index (based on four stress-related scales) was associated with decreases in percentage body fat in early childhood (SI 11.1). Additionally, data regarding circulating leptin levels was extracted from one study (Entriger S [41]) where authors reported increased levels of leptin in young adults whose mothers experienced major stressful life events during their pregnancy, compared with control subjects (SI 11.1).

\section{Systematic review on the relationship between PS and blood pressure, glucose metabolism, and circulating lipids}

The relation between PS and outcomes other than BMI or body fat had only been investigated by a small number of researchers and therefore enough data to calculate an appropriate overall effect size could not be obtained.

We extracted blood pressure data from five separate publications (SI 11.2). In school age children participants of the Generation R Study, maternal psychological distress, by means of family stress or hostility symptoms, were not associated with childhood systolic or diastolic blood pressure. High family stress reported by the mother was positively associated with a higher childhood diastolic blood pressure, but not with childhood systolic blood pressure. 
However, after adjustment for various potential confounders these associations did not remain significant [51]. In the Amsterdam Born Children and their Development (ABCD) study job strain was not associated with systolic or diastolic blood pressure in the child at age 5-7 years. Moreover, hypertension, defined using guidelines from the Fourth Report on the Diagnosis, Evaluation, and Treatment of High Blood Pressure in Children and Adolescents, was not associated with job strain in this sample [52]. Two separate studies described the relationship between maternal exposure to earthquake during pregnancy (as a surrogate for PS) and blood pressure later in adult life. In one study, the systolic pressure was significantly higher in the prenatal earthquake stress group compared to that in the control group, but no significant differences were found for diastolic pressure [55]. In the other study, prenatal exposure to the earthquake was not associated with systolic or diastolic blood pressure [47]. Finally, a study showed an opposite effect. PS (life stress events) was inversely related to systolic and diastolic blood pressure in young adult offspring participants of the Raine Study. Furthermore, PS predicted lower odds of systolic (pre)hypertension (SBP $\geq 120 \mathrm{mmHg}$ ) [35].

Table SI 11.3 shows data collected on the relationship between PS and offspring's glucose metabolism. Four studies on offspring's glucose and PS were identified in our review and all of them found no association between glucose and PS (negative life events, job strain and exposure to earthquake) [41, 47, 54, 55]. We found only one study reporting on PS and insulin without significant assoaciations [41].

A total of three studies on triglycerides were included in the systematic review (SI 11.4) and the three of them found no association between circulating triglycerides and PS (negative life events and exposure to earthquake) [41, 47, 55]. Finally, the association between PS and HDL-C was investigated in two studies with contradictory results (SI 11.4). One study showed that subjects exposed to PS (negative life events) had 16\% lower HDL-C levels [41]; however a different study found no significant differences for HDL-C between prenatal earthquake stress and control subjects [55].

\section{Discussion}

We have systematically collected the available data on effects of PS on offspring's phenotypic outcomes related to obesity risk, metabolic function, and blood pressure. In a first meta-analysis the key finding was that the overall effect size (d) of the effect of PS on BMI was positive. Heterogeneity was detected meaning that studies on the association between PS and BMI have yielded mixed results. Differences in methodology may, at least partly, be responsible for this 
inconsistency. Dataset source, study design, intervention span, stress type and age stage were detected as sources of putative heterogeneity. Importantly, subgroup analysis detected that the association between PS and BMI was lost in historical studies. Thus, study design can certainly influence the conclusions of different studies. Both objective and subjective PS have been linked to increased BMI. Furthermore, subgroup analysis did not find a significant difference between different data sources, although due to the unbalanced nature of sample sizes in our data subsets, we could not perform all of the planned subgroup analysis. Finally, meta-regression analysis showed that age, male ratio and ethnicity may have no significant effect on effect size.

A second but explorative meta-analysis was performed synthesizing five studies investigating the association between PS and body fat. The overall standardized mean difference effect size was positive with no heterogeneity, however, the leaving-one-out study detected that results were not consistent. As exclusion of specific datasets may modulate the association between PS and body fat, more large-scale studies are required to throw light into this association. Furthermore, publication bias was evident in body fat dataset. Overestimation of effect size potentially could occur as negative studies are less likely to be published in journals. Furthermore, the single study not included in quantitative metaanalysis (Wu S [57]) showed an inverse significant association.

It must be noted that relevant outcomes including blood pressure, glucose metabolism and circulating lipids have only been assessed in a limited number of studies and individuals to date. Noticeably, six out of seven investigations on PS exposure and these metabolic outcomes were published between 2012 and 2017, with only one study previously in 2008; reflecting that there is an increasing interest in the area. Regarding the association between stress exposure during pregnancy and blood pressure, the results of five research studies were inconsistent. Of note, Bhat SK and collaborators have reported an inverse relationship between prenatal stress and adult SBP, which was accentuated by a higher BMI [35]. Although some epidemiological studies have shown, paradoxically, that individuals with metabolically healthy overweight/obesity did not always exhibit higher rates of cardio- metabolic diseases; a meta-analysis of prospective cohort studies has demonstrated that the risk of hypertension is increased in both metabolically unhealthy and metabolically healthy obese phenotypes [59]. Obesity is well-known as a risk factor for development of hypertension. A recent updated meta-analysis (2018) has shown that waist-toheight ratio, waist-to-hip ratio and BMI were all associated with hypertension risk [60]. Furthermore, a dose-response meta-analysis demonstrated that the risk of hypertension increased continuously with increasing all anthropometric 
measures; e.g., the risk of hypertension increased by $49 \%$ per a five-unit increment in BMI [61].

Some aspects of our meta-analysis deserve discussion. Unpublished and nonEnglish data could not be considered in meta-analysis for practical reasons and we limited search to data obtained from studies indexed by selected database. Including all study results was also challenging because of varying methods for assessing associations. Operationalization of stress exposure varied widely between the included studies and in future meta-analyses exposure variable should be normalized as much as possible and ideally should include cortisol values or any other measure of physical load. Although self-completion questionnaires and interviews are still the most commonly used methods, new technology is increasingly providing opportunities to make progress in stress measurement.

A recent meta-analysis synthesized results from studies of maternal stress during infancy and childhood, finding higher risk of obesity in children when mothers experienced stress, and children's own experience of stress seemed to exacerbate the association between maternal stress and subsequent higher child obesity risk [62]. Prospective human studies to date also suggest that accelerated infant growth, promoted in part by calorie-rich diets or early overfeeding, may program principal components of the MetS, including obesity, insulin resistance and cardiovascular disease $[63,64,65]$. It may be speculated that PS per se may give rise to subtle adverse effects, and abnormal phenotype may be provoked by or exacerbated in a later life challenging environment. Additionally, different postnatal factors may further account for overweight later in life. The effects of well-known risk factors such as family history of disease, socioeconomic status, lifestyle habits (e.g., physical activity, smoking, alcohol- and drug use), and nutrition should be also taken into consideration. The question therefore remains to what extent associations between PS and postnatal metabolic alterations can be modulated by changes in biological and social risk factors. Future research examining the relationship between PS exposure and offspring metabolic outcomes should therefore include potentially relevant confounders with adequate assessment of mother and child lifestyle variables. In light of the current dietary and stress environment that many humans live in, it is important to address whether PS may exacerbate the effects of postnatal nutritional and stressful insults.

Based on findings presented here on studies on human research and the conceptual framework we conclude that experiencing a stressful situation during development in the uterus is associated to a predisposition to increased overweight risk, owning to an increase in BMI, and/or a possible increase in 
body fat. In this systematic review we could not find conclusive evidence for abnormal MetS intermediate phenotypes caused by stress exposure in utero, beyond overweight; although there is an increasing interest in the area and future systematic reviews would help to contribute to this knowledge area.

Although quantitative evidence supports an association between prenatal stressors and overweight and biological plausibility does exist, the link is simply associational. More studies are required to understand the underlying fundamental molecular mechanisms related to the role of the interactions between genome, epigenome, maternal environment and postnatal environment. PS through stress hormones or through other pathophysiological and/or genetic mechanisms may program lifespan offspring's stress biology, probably via epigenetic mechanisms [66]. It has been demonstrated that PS can lead to an increase in DNA methylation at specific CpG sites within the $11 \beta-H S D 2$ gene promoter in the placenta [67]. Furthermore, several studies have looked at alterations in the methylation of other genes, e.g., the glucocorticoid receptor (NR3C1) [68]. Other potential programming mechanism may include effects of PS on telomere biology [69].

\section{Supplementary information}

The online version of this article (https://doi.org/10.1038/s41366-019-0423-z) contains supplementary material, which is available to authorized users.

Publisher's note: Springer Nature remains neutral with regard to jurisdictional claims in published maps and institutional affiliations.

\section{Acknowledgements}

This study was partially supported by grants PICT-2015-1567, PICT 2016-2727 (Agencia Nacional de Promoción Científica Tecnológica) and PIP 2015-2017 No. 11220150100163 (Consejo Nacional de Investigaciones Científicas y Técnicas). ALB, AMG, and MLT are members of Consejo Nacional de Investigaciones Científicas y Técnicas.

Compliance with ethical standards

Conflict of interest The authors declare that they have no conflict of interest.

\section{Supplementary information}

Supporting Information 


\section{References}

1. Kivimaki M, Steptoe A. Effects of stress on the development and progression of cardiovascular disease. Nat Rev Cardiol. 2018;15:215-29.

2. Chrousos GP. Stress and disorders of the stress system. Nat Rev Endocrinol. 2009;5:374-81.

3. Barker DJ. Fetal origins of coronary heart disease. BMJ. 1995;311:171-4.

4. Danaei G, Finucane MM, Lu Y, Singh GM, Cowan MJ, Paciorek CJ, et al. National, regional, and global trends in fasting plasma glucose and diabetes prevalence since 1980: systematic analysis of health examination surveys and epidemiological studies with 370 country-years and 2.7 million participants. Lancet. 2011;378:31-40.

5. Ozanne SE, Hales CN. Pre- and early postnatal nongenetic determinants of type 2 diabetes. Expert Rev Mol Med. 2002;4:1-14.

6. Bercovich E, Keinan-Boker L, Shasha SM. Long-term health effects in adults born during the Holocaust. Isr Med Assoc J. 2014;16:203-7.

7. Flory JD, Bierer LM, Yehuda R. Maternal exposure to the holocaust and health complaints in offspring. Dis Markers. 2011;30:133-9.

8. Painter RC, de Rooij SR, Bossuyt PM, Phillips DI, Osmond C, Barker DJ, et al. Blood pressure response to psychological stressors in adults after prenatal exposure to the Dutch famine. J Hypertens. 2006;24:1771-8.

9. Poggi Davis E, Sandman C. Prenatal exposure to stress and stress hormones influences child development. Infants Young Child. 2006;19:24659.

10. Roseboom T, de Rooji S, Painter R. The Dutch famine and its long-term consequences for adult health. Early Hum Dev. 2006;82:485-91.

11. Christian LM, Franco A, Glaser R, Iams JD. Depressive symptoms are associated with elevated serum proinflammatory cytokines among pregnant women. Brain Behav Immun. 2009;23:750-4. 
12. Gitau R, Cameron A, Fisk NM, Glover V. Fetal exposure to maternal cortisol. Lancet. 1998;352:707-8.

13. Edwards CR, Benediktsson R, Lindsay RS, Seckl JR. Dysfunction of placental glucocorticoid barrier: link between fetal environment and adult hypertension? Lancet. 1993;341:355-7.

14. Meaney MJ, Szyf M, Seckl JR. Epigenetic mechanisms of perinatal programming of hypothalamic-pituitary-adrenal function and health. Trends Mol Med. 2007;13:269-77.

15. Benediktsson R, Lindsay RS, Noble J, Seckl JR, Edwards CR.

Glucocorticoid exposure in utero: new model for adult hypertension. Lancet. 1993;341:339-41.

16. Brown RW, Diaz R, Robson AC, Kotelevtsev YV, Mullins JJ, Kaufman $\mathrm{MH}$, et al. The ontogeny of 11 beta-hydroxysteroid dehydrogenase type 2 and mineralocorticoid receptor gene expression reveal intricate control of glucocorticoid action in development. Endocrinology. 1996;137:794-7.

17. McTernan CL, Draper N, Nicholson H, Chalder SM, Driver P, Hewison M, et al. Reduced placental 11beta-hydroxysteroid dehydrogenase type 2 mRNA levels in human pregnancies complicated by intrauterine growth restriction: an analysis of possible mechanisms. J Clin Endocrinol Metab. 2001;86:4979-83.

18. Drake AJ, Liu L, Kerrigan D, Meehan RR, Seckl JR. Multigenerational programming in the glucocorticoid programmed rat is associated with generation-specific and parent of origin effects. Epigenetics. 2011;6:1334-43.

19. Harris A, Seckl J. Glucocorticoids, prenatal stress and the programming of disease. Horm Behav. 2011;59:279-89.

20. Littleton HL, Bye K, Buck K, Amacker A. Psychosocial stress during pregnancy and perinatal outcomes: a meta-analytic review. J Psychosom Obstet Gynaecol. 2010;31:219-28.

21. Barker DJ, Hales CN, Fall CH, Osmond C, Phipps K, Clark PM. Type 2 (non-insulin-dependent) diabetes mellitus, hypertension and hyperlipidaemia (syndrome X): relation to reduced fetal growth. Diabetologia. 1993;36:62-7. 
22. Phillips DI, Barker DJ, Hales CN, Hirst S, Osmond C. Thinness at birth and insulin resistance in adult life. Diabetologia. 1994;37:150-4.

23. van Montfoort N, Finken MJ, le Cessie S, Dekker FW, Wit JM. Could cortisol explain the association between birth weight and cardiovascular disease in later life? A meta-analysis. Eur J Endocrinol. 2005;153:811-7.

24. Reynolds RM. Corticosteroid-mediated programming and the pathogenesis of obesity and diabetes. J Steroid Biochem Mol Biol. 2010;122:3-9.

25. Entringer S. Impact of stress and stress physiology during pregnancy on child metabolic function and obesity risk. Curr Opin Clin Nutr Metab Care. $2013 ; 16: 320-7$.

26. Virk J, Li J, Vestergaard M, Obel C, Kristensen JK, Olsen J. Prenatal exposure to bereavement and type-2 diabetes: a Danish longitudinal population based study. PLoS ONE. 2012;7:e43508.

27. Moher D, Liberati A, Tetzlaff J, Altman DG. Preferred reporting items for systematic reviews and meta-analyses: the PRISMA statement. J Clin Epidemiol. 2009;62:1006-12.

28. Stroup DF, Berlin JA, Morton SC, Olkin I, Williamson GD, Rennie D, et al. Meta-analysis of observational studies in epidemiology: a proposal for reporting. Meta-analysis Of Observational Studies in Epidemiology (MOOSE) group. JAMA. 2000;283:2008-12.

29. Alder J, Fink N, Bitzer J, Hosli I, Holzgreve W. Depression and anxiety during pregnancy: a risk factor for obstetric, fetal and neonatal outcome? A critical review of the literature. J Matern Fetal Neonatal Med. 2007;20:189209.

30. Littleton HL, Breitkopf CR, Berenson AB. Correlates of anxiety symptoms during pregnancy and association with perinatal outcomes: a metaanalysis. Am J Obstet Gynecol. 2007;196:424-32.

31. Wells JC. The thrifty phenotype hypothesis: thrifty offspring or thrifty mother? J Theor Biol. 2003;221:143-61.

32. Tellechea ML, Mensegue MF, Pirola CJ. The association between high fat diet around gestation and metabolic syndrome-related phenotypes in rats: 
a systematic review and meta-analysis. Sci Rep. 2017;7:5086.

33. Peterson RA, Brown SP. On the use of beta coefficients in meta-analysis. J Appl Psychol. 2005;90:175-81..

34. Higgins JP, Thompson SG, Deeks JJ, Altman DG. Measuring inconsistency in meta-analyses. BMJ. 2003;327:557-60.

35. Bhat SK, Beilin LJ, Robinson M, Burrows S, Mori TA. Contrasting effects of prenatal life stress on blood pressure and body mass index in young adults. J Hypertens. 2015;33:711-9.

36. Chatterjee A, Thompson JW, Svensson K, Tamayo YO, Wright R, Wright $\mathrm{R}$, et al. Maternal antenatal stress has little impact on child sleep: results from a prebirth cohort in Mexico City. Sleep Health. 2018;4:397-404.

37. Christensen JS, Hjortebjerg D, Raaschou-Nielsen O, Ketzel M, Sorensen TIA, Sorensen M. Pregnancy and childhood exposure to residential traffic noise and overweight at 7 years of age. Environ Int. 2016;94:170-6.

38. Dancause KN, Veru F, Andersen RE, Laplante DP, King S. Prenatal stress due to a natural disaster predicts insulin secretion in adolescence. Early Hum Dev. 2013;89:773-6.

39. Dancause KN, Laplante DP, Hart KJ, O’Hara MW, Elgbeili G, Brunet A, et al. Prenatal stress due to a natural disaster predicts adiposity in childhood: the Iowa Flood Study. J Obes. 2015;2015:570541.

40. Dixon B, Rifas-Shiman SL, James-Todd T, Ertel K, Krieger N, Kleinman $\mathrm{KP}$, et al. Maternal experiences of racial discrimination and child weight status in the first 3 years of life. J Dev Orig Health Dis. 2012;3:433-41.

41. Entringer S, Wust S, Kumsta R, Layes IM, Nelson EL, Hellhammer DH, et al. Prenatal psychosocial stress exposure is associated with insulin resistance in young adults. Am J Obstet Gynecol. 2008;199:498-7.

42. Farewell CV, Thayer ZM, Tracer DP, Morton S. Prenatal stress exposure and early childhood BMI: exploring associations in a New Zealand context. Am J Hum Biol. 2018;30:e23116.

43. Guxens M, Tiemeier H, Jansen PW, Raat H, Hofman A, Sunyer J, et al. Parental psychological distress during pregnancy and early growth in 
preschool children: the generation R study. Am J Epidemiol. 2013;177:53847.

44. Hohwu L, Li J, Olsen J, Sorensen TI, Obel C. Severe maternal stress exposure due to bereavement before, during and after pregnancy and risk of overweight and obesity in young adult men: a Danish National Cohort Study. PLoS ONE. 2014;9:e97490.

45. Hohwu L, Zhu JL, Graversen L, Li J, Sorensen TI, Obel C. Prenatal parental separation and body weight, including development of overweight and obesity later in childhood. PLoS ONE. 2015;10:e0119138.

46. Ingstrup KG, Schou AC, Ajslev TA, Pedersen P, Sorensen TI, Nohr EA. Maternal distress during pregnancy and offspring childhood overweight. J Obes. 2012;2012:462845.

47. Ji C, Li Y, Cui L, Cai J, Shi J, Cheng FW, et al. Prenatal earthquake exposure and midlife uric acid levels among Chinese adults. Arthritis Care Res. 2017;69:703-8.

48. Li J, Olsen J, Vestergaard M, Obel C, Baker JL, Sorensen TI. Prenatal stress exposure related to maternal bereavement and risk of childhood overweight. PLoS ONE. 2010;5:e11896.

49. Liu GT, Dancause KN, Elgbeili G, Laplante DP, King S. Disaster-related prenatal maternal stress explains increasing amounts of variance in body composition through childhood and adolescence: Project Ice Storm. Environ Res. 2016;150:1-7.

50. Sandel M, Sheward R, Ettinger de Cuba S, Coleman S, Heeren T, Black $\mathrm{MM}$, et al. Timing and duration of pre- and postnatal homelessness and the health of young children. Pediatrics. 2018;142:e20174254.

51. Taal HR, de Jonge LL, Tiemeier H, van Osch-Gevers L, Hofman A, Verhulst FC, et al. Parental psychological distress during pregnancy and childhood cardiovascular development. The Generation R Study. Early Hum Dev. 2013;89:547-53.

52. van Dijk AE, van EM, Stronks K, Gemke RJ, Vrijkotte TG. The association between prenatal psychosocial stress and blood pressure in the child at age 5-7 years. PLoS ONE. 2012;7:e43548. 
53. van Dijk AE, van Eijsden M, Stronks K, Gemke RJ, Vrijkotte TG. The relation of maternal job strain and cortisol levels during early pregnancy with body composition later in the 5-year-old child: the ABCD study. Early Hum Dev. 2012;88:351-6.

54. van Dijk AE, van Eijsden M, Stronks K, Gemke RJ, Vrijkotte TG. No associations of prenatal maternal psychosocial stress with fasting glucose metabolism in offspring at 5-6 years of age. J Dev Orig Health Dis. 2014;5:361-9.

55. Wang R, An C, Wang J, Wang Y, Song M, Li N, et al. Earthquake experience at different trimesters during pregnancy is associated with leukocyte telomere length and long-term health in adulthood. Front Psychiatry. 2017;8:208.

56. Weyde KV, Krog NH, Oftedal B, Magnus P, White R, Stansfeld S, et al. A longitudinal study of road traffic noise and body mass index trajectories from birth to 8 years. Epidemiology. 2018;29:729-38.

57. Wu S, Gennings C, Wright RJ, Wilson A, Burris HH, Just AC, et al. Prenatal stress, methylation in inflammation-related genes, and adiposity measures in early childhood: the Programming Research in Obesity, Growth Environment and Social Stress Cohort Study. Psychosom Med. 2018;80:3441.

58. Zadzinska E, Rosset I. Pre-natal and perinatal factors affecting body mass index in pre-pubertal Polish children. Ann Hum Biol. 2013;40:477-84.

59. Mirzababaei A, Djafarian K, Mozafari H, Shab-Bidar S. The long-term prognosis of heart diseases for different metabolic phenotypes: a systematic review and meta-analysis of prospective cohort studies. Endocrine. 2019;63:439-62.

60. Deng G, Yin L, Liu W, Liu X, Xiang Q, Qian Z. et al. Associations of anthropometric adiposity indexes with hypertension risk: a systematic review and meta-analysis including PURE-China. Medicine. 2018;97:e13262

61. Jayedi A, Rashidy-Pour A, Khorshidi M, Shab-Bidar S. Body mass index, abdominal adiposity, weight gain and risk of developing hypertension: a systematic review and dose-response meta-analysis of more than 2.3 million participants. Obes Rev. 2018;19:654-67. 
62. Tate EB, Wood W, Liao Y, Dunton GF. Do stressed mothers have heavier children? A meta-analysis on the relationship between maternal stress and child body mass index. Obes Rev. 2015;16:351-61.

63. Stettle N, Stallings VA, Troxel AB, Zhao J, Schinnar R, Nelson SE, et al. Weight gain in the first week of life and overweight in adulthood: a cohort study of European American subjects fed infant formula. Circulation. 2005;111:1897-903.

64. Singhal A, Cole TJ, Fewtrell M, Deanfield J, Lucas A. Is slower early growth beneficial for long-term cardiovascular health? Circulation. 2004;109:1108-13.

65. Stettler N, Zemel BS, Kumanyika S, Stallings VA. Infant weight gain and childhood overweight status in a multicenter, cohort study. Pediatrics. 2002;109:194-9.

66. Cao-Lei L, de Rooij SR, King S, Matthews SG, Metz GAS, Roseboom TJ, et al. Prenatal stress and epigenetics. Neurosci Biobehav Rev. 2017. $\mathrm{AQ7}$

67. Jensen PC, Monk C, Champagne FA. Epigenetic effects of prenatal stress on 11beta-hydroxysteroid dehydrogenase- 2 in the placenta and fetal brain. PLoS ONE. 2012;7:e39791.

68. Glover V, O’Donnell KJ, O'Connor TG, Fisher J. Prenatal maternal stress, fetal programming, and mechanisms underlying later psychopathology —a global perspective. Dev Psychopathol. 2018;30:843-54.

69. Entringer S, Epel ES, Kumsta R, Lin J, Hellhammer DH, Blackburn EH, et al. Stress exposure in intrauterine life is associated with shorter telomere length in young adulthood. Proc Natl Acad Sci USA. 2011;108:E513-8. 